Buchalska J., Chmielewski K., Doczekalska J., The concept of corporate reputation in marketing and Polish law - the search for interdisciplinary communication, „Ekonomia i Prawo. Economics and Law", Polszakiewicz B., Boehlke J. (ed.), Vol. 14, No. 2/2015, pp. 189-203. DOI: http:// dx.doi.org/10.12775/EiP.2015.011.

\author{
Joanna Buchalska*, Krzysztof Chmielewski", \\ AGNIESZKA DOCZEKALSKA*
}

\title{
THE CONCEPT OF CORPORATE REPUTATION IN MARKETING AND POLISH LAW - THE SEARCH FOR INTERDISCIPLINARY COMMUNICATION
}

\section{SUMMARY}

The paper aims to compare how the concept of corporate reputation is understood in the fields of law and marketing. This comparative investigation determines whether interdisciplinary communication between these two domains, and consequently interdisciplinary research on corporate reputation, is possible.

Due to the lack of a legal definition (i.e. definition in a legal act) of corporate reputation, the meaning of this concept is reconstructed on the basis of Polish legislation and case law. Then the legal concept of corporate reputation is compared with numerous definitions proposed by marketing scholars. As a result of this investigation, two approaches to corporate reputation are distinguished: reputation as a process and reputation as a result. Legal scholars focus on the latter, whereas marketing researchers consider both approaches. This difference results from diverse objectives of mar-

" Joanna Buchalska, Koźminski University, Department of Civil Law, ul. Jagiellońska 57/59, 03-301 Warszawa, Poland, phone: +48 2251922 30, e-mail: jbuchalska@kozminski.edu.pl (cor-responding author).

** Krzysztof Chmielewski, Koźminski University, Department of Marketing, ul. Jagiellońska 57/59, 03-301 Warszawa, Poland, phone: +48 2251922 30, e-mail: kchmielew-ski@kozminski.edu.pl.

"** Agnieszka Doczekalska, Koźminski University, Department of Philosophy and Theory of Law, ul. Jagiellońska 57/59, 03-301 Warszawa, Poland, phone: +48 2251922 30, e-mail: ado-czekalska@kozminski.edu.pl. 
keting and legal research on corporate reputation. The former aims at developing a good reputation (process) and evaluating it (reputation as a result), while the latter focuses on protecting corporate reputation (reputation as a result). Despite the differences in approaches towards the concept, interdisciplinary research is not only possible (especially, when both domains investigate reputation as a result), but also needed, as both lawyers and marketing experts operate in the same market and have the same client, i.e. an entrepreneur. The comparative analysis explained in this paper is the first step to bringing legal and marketing knowledge together.

Keywords: corporate reputation, corporation/enterprise, entrepreneur, marketing, intellectual property law, interdisciplinary research

JEL Classification: K1, M3

\section{INTRODUCTION}

"Reputation" is a term of ordinary language as well as of languages applied by scholars within several academic disciplines, such as marketing, management, economic and political science, law, and social psychology. Reputation does not mean the same in all of these disciplines, as this term can refer to various objects, such as a person, a social group, a corporation, an organization, a trademark or a brand. Moreover, since scholars analyze different facets of reputation, even within one discipline they can define the term diversely.

This paper focuses on the meaning of corporate reputation as it is understood in the domain of marketing and Polish law. The comparative analysis of this concept will reveal whether communication between the two domains is possible and, as a result, whether interdisciplinary research on corporate reputation can be conducted.

Firstly, the paper aims to find out whether a uniform definition of corporate reputation is provided in the domain of marketing or law. The term "corporate reputation" is comprised of two terms. Therefore, it is necessary to examine whether both disciplines investigate the reputation of the same entity or at least similar entities. Consequently, the meaning of corporation in law and marketing must be scrutinized. Next, with the legal and marketing definitions of corporate reputation in hand, it is possible to evaluate whether the legal and marketing concepts are comparable. Finally, to understand the core meaning of corporate reputation, the reasons why this concept has been developed in the domain of marketing and of law are explained. As a result of this analysis, the paper will determine whether marketing and legal research about corporate reputation can be merged or should be left separate. 


\section{THE CURRENT STATE OF KNOWLEDGE: THE CONCEPT OF CORPORATE REPUTATION IN THE FIELD OF LAW AND MARKETING}

Reputation is not a new concept created for the purpose of the business, law, or academic worlds. It is a term of ordinary language and has been defined, for example, by the Merriam-Webster dictionary as "the common opinion that people have about someone or something" ${ }^{1}$. Very similar definitions of this concept can be found in other English ${ }^{2}$ and in Polish dictionaries ${ }^{3}$.

Before the meaning of corporate reputation in law and marketing is explained, one terminological remark is necessary. Polish marketing scholars use the term "reputacja przedsiębiorstwa" as the Polish equivalent of corporate reputation, whereas in Polish legalese 4 the term "renoma przedsiębiorstwa" (corporate repute) is preferred. In the English legalese of the British and American legal systems, such a terminological distinction is unknown, and the same term "corporate reputation" is applied in the legal and marketing domains.

\subsection{NO LEGAL DEFINITION OF CORPORATE REPUTATION}

In the Polish legal system, the protection of corporate reputation is especially guaranteed in the Civil Code $^{5}$ and the Suppression of Unfair Competition $\mathrm{Act}^{6}$ (article 26). However, corporate reputation is not defined in these legal acts. To the best knowledge of the authors, such a definition has not yet been developed by Polish legal scholars either. On the one hand, a legal definition of reputation could guarantee that judges - in case of harm to

${ }_{1}$ Merriam-Webster, Reputation, http://www.merriam-webster.com/dictionary/reputation (22.09.2014).

${ }^{2}$ Cf. definitions of reputation from various dictionaries at The Free Dictionary, http://www. thefreedictionary.com/reputation (20.12.2014).

${ }^{3}$ Cf. for instance, definitions of reputation in dictionaries of PWN, available at Słownik Języka Polskiego, http://sjp.pwn.pl/szukaj/reputacja.html (20.12.2014).

${ }^{4}$ In legal theory, there is a distinction between legalese (język prawniczy), which is a language used to speak or write about law and statutory language (język prawny), which is a language of legal acts; B. Wróblewski, Jezzyk prawny i prawniczy, Polska Akademia Umiejętności, Kraków 1948.

${ }^{5}$ Ustawa z dnia 23 kwietnia 1964 r. - Kodeks cywilny (Civil Code, April 23, 1964), Dz.U., No. 16, item 93 with subsequent amendments, art. 431-4310.

${ }^{6}$ Obwieszczenie Marszatka Sejmu Rzeczypospolitej Polskiej z dnia 26 czerwca 2003 r. w sprawie ogtoszenia jednolitego tekstu ustawy o zwalczaniu nieuczciwej konkurencji (Suppression of Unfair Competition Act of June 26, 2003), Dz.U., No. 153, item 1503 with subsequent amendments, art. 26. 
reputation - will deal with issues of recoverability and measuring damages in a uniform manner ${ }^{7}$. However, the lack of the definition gives judges room to evaluate in each individual case whether a reputation has been harmed, and consequently arrive at the fairest judgment.

Judges of Polish administrative courts attempted to define a legal concept of reputation. According to them corporate reputation is a set of positive impressions and evaluations about an entrepreneur ${ }^{8}$, which can result in the development of the trademark reputation'.

Although there is no legal definition of corporate reputation in the Polish legal system, the concept of reputational harm can be reconstructed from an analysis of the above mentioned legal provisions (legislation) and their judicial interpretation (case law). As a result of this investigation, the following examples of reputational harm can be indicated:

- Dissemination of untrue or misleading information about an enterprise and, in particular, about persons managing the enterprise, manufactured goods, services provided or prices, or the economic or legal situation of the enterprise with the intention of causing injury to an entrepreneur (Article 26 of the Suppression of Unfair Competition Act) ${ }^{10}$;

- Dissemination of untrue information about the unreliability of a debtor ${ }^{11}$;

- Unlawful use of the name, surname or pseudonym (alias) associated with the reputation of an enterprise ${ }^{12}$;

- Prejudicial statements attributing misconduct to a legal person, especially when such an attribution could result in losing trust ${ }^{13}$; and

- Unjustified criticism not based on the relevant background and facts ${ }^{14}$.

Analysis of the examples of reputational harm discloses what is protected by the law and hence how corporate reputation is understood in the Polish legal system. Consequently, corporate reputation in the law can be described as a good name reflected, e.g., in the quality of manufactured goods and provided services, in the economic or legal situation of the corporation, the reliability of an entrepreneur in performing his or her obligations, and in trust

7 D. Saidov, Damages: The Need for Uniformity, "Journal of Law and Commerce" Vol. 25, No. $1 / 2005$, p. 396.

${ }^{8}$ Judgment of the District Administrative Court of November 11, 2008, VI SA/Wa 1388/07; Judgment of the District Administrative Court of February 6, 2009, VI SA/Wa 1483/08.

9 Judgment of the Supreme Court of October 16, 2014, III CSK 275/13.

${ }_{10}$ Judgment of the Court of Appeals in Warsaw of May 23, 2006, VI ACa 1221/05.

${ }_{11}$ Judgment of the Court of Appeals in Warsaw of May 23, 2006, VI ACa 1221/05.

12 Judgment of the Court of Justice of June 18, 2009, C-487/07.

${ }_{13}$ Judgment of the Supreme Court of June 6, 2005, III CK 622/04.

${ }^{14}$ Judgment of the Supreme Administrative Court of September 6, 2013, I ACa 456/13. 
in the corporation. This observation is in accordance with the general definitions of reputation found in English legal dictionaries. Although the dictionaries do not define "corporate reputation" distinctly, they provide information on how reputation can be understood in the law. For instance, Featuring Black's Law Dictionary defines reputation as "a person's credit, honor, character, good name"15.

Moreover, the close look at reputational harms reveals that law intervenes to protect corporate reputation not only when dissemination of untrue or misleading information about the corporation can jeopardize a good reputation, but also when the name, surname or pseudonym associated with the reputation of a corporation is unlawfully used by another entity. Hence, a company can gain advantages by associating with the good reputation of another corporation.

\subsection{NUMEROUS DEFINITIONS OF CORPORATE REPUTATION IN THE FIELD OF MARKETING}

The lack of a legal definition of corporate reputation is in stark contrast with numerous definitions of this concept developed by marketing scholars ${ }^{16}$. They concentrate mostly on corporate reputation in comparison to endorsers or spokespersons, who represent the individual/consumer side of reputation (also called credibility). However, credibility is seen here as a mixture of expertise, attractiveness, and trustworthiness ${ }^{17}$. But today there is still the need for a definitional consensus and even most of the academic papers lack a proper definition of corporate reputation ${ }^{18}$. This becomes clear when looking at table 1 and comparing the definitions with each other.

15 Featuring Black's Law Dictionary, http://thelawdictionary.org (20.12.2014).

16 The increased importance of the corporate reputation can be seen directly in various rankings. For instance the Fortune magazine "Most Admired Companies" ranking or the Harris Poll "Reputation Quotient (RQ)" study or indirectly by having a favorable position in the mind of the stakeholders. Other measurable outcomes of "good" reputation are for example: higher price to earnings ratio, and therefore a higher market capitalization; stronger business ties with distributors as people prefer to do business with companies they like; and being a step ahead in the war for talent as employees like to work for a company which has a good reputation; see R.J. Burke, Corporate Reputations: Development, Maintenance, Change and Repair, [in:] R.J. Burke, G. Martin, C.L. Cooper (ed.), Corporate Reputation. Managing Opportunities and Threats, Gower, Farnham, Surrey 2011, pp. 3-4.

17 H.M. Parker, J.S. Fink, Arrest Record or Openly Gay: The Impact of Atbletes' Personal Lives on Endorser Effectiveness, „Sport Marketing Quarterly”, Vol. 21, No. 2/2012, pp. 70-79.

${ }^{18}$ K. Walker, A Systematic Review of the Corporate Reputation Literature: Definition, Measurement, and Theory, „Corporate Reputation Review”, Vol. 12, No. 4/2010, pp. 357-387. 
When reviewing the various definitions of corporate reputation, it is apparent that reputation varies with the different stakeholder groups based on their perceptions, history with the company or interaction. Different scholars put more emphasis on the stakeholder groups which they find the most important, i.e. the individual level, the macro and micro level, or even as a subtopic within another discipline like public relations ${ }^{19}$. Therefore, corporate reputation cannot be treated as a standalone silo but always within the system of different stakeholders and disciplines. However, it cannot be forgotten that corporate reputation starts from the inside out, meaning that the company is the starting point of all good or bad ${ }^{20}$.

Table 1. Definitions of Corporate Reputation

\begin{tabular}{|c|c|c|}
\hline No. & AUTHOR(S), YEAR & DEFINITION \\
\hline 1 & $\begin{array}{l}\text { Weigelt and Camer- } \\
\text { er, } 1988\end{array}$ & A set of attributes ascribed to a firm, inferred from the firm's past actions. \\
\hline 2 & $\begin{array}{l}\text { Fombrun and Shan- } \\
\text { ley, } 1990\end{array}$ & $\begin{array}{l}\text { The outcome of a competitive process in which firms signal their key characteris- } \\
\text { tics to constituents to maximize their social status. }\end{array}$ \\
\hline 3 & Fombrun, 1996 & $\begin{array}{l}\text { A perceptual representation of a company's past actions and future prospects that } \\
\text { describes the firm's overall appeal to all of its key constituents when compared } \\
\text { with other leading rivals. }\end{array}$ \\
\hline 4 & $\begin{array}{l}\text { Fombrun and Van } \\
\text { Riel, } 1997\end{array}$ & $\begin{array}{l}\text { A corporate reputation is a collective representation of a firm's past actions and re- } \\
\text { sults that describes the firm's ability to deliver valued outcomes to multiple stake- } \\
\text { holders. It gauges a firm's relative standing both internally with employees and ex- } \\
\text { ternally with its stakeholders, in both its competitive and institutional environment. }\end{array}$ \\
\hline 5 & $\begin{array}{l}\text { Cable and Graham, } \\
2000\end{array}$ & A public's affective evaluation of a firms' name relative to other firms. \\
\hline 6 & Deephouse, 2000 & $\begin{array}{l}\text { The evaluation of a firm by its stakeholders in terms of their affect, esteem, and } \\
\text { knowledge. }\end{array}$ \\
\hline 7 & Bromley, 2001 & $\begin{array}{l}\text { A distribution of opinions (the overt expressions of a collective image) about a per- } \\
\text { son or other entity, in a stakeholder or interest group. }\end{array}$ \\
\hline 8 & $\begin{array}{l}\text { Gotsi and Wilson, } \\
2001\end{array}$ & $\begin{array}{l}\text { A corporate reputation is a stakeholder's overall evaluation of a company over time. } \\
\text { This evaluation is based on the stakeholder's direct experiences with the company, } \\
\text { any other form of communication and symbolism that provides information about } \\
\text { the firm's actions and/or a comparison with the actions of other leading rivals }\end{array}$ \\
\hline 9 & $\begin{array}{l}\text { Whetten and Mack- } \\
\text { ey, } 2002\end{array}$ & $\begin{array}{l}\text { Organizational reputation is a particular type of feedback, received by an organi- } \\
\text { zation from its stakeholders, concerning the credibility of the organization's iden- } \\
\text { tity claims. }\end{array}$ \\
\hline 10 & $\begin{array}{l}\text { Rindova, William- } \\
\text { son, Petkova and } \\
\text { Sever, } 2005\end{array}$ & $\begin{array}{l}\text { Stakeholders' perceptions about an organization's ability to create value relative } \\
\text { to competitors. }\end{array}$ \\
\hline 11 & $\begin{array}{l}\text { Rhee and Haun- } \\
\text { schild, } 2006\end{array}$ & The consumer's subjective evaluation of the perceived quality of the producer. \\
\hline 12 & Carter, 2006 & A set of key characteristics attributed to a firm by various stakeholders. \\
\hline
\end{tabular}

${ }^{19}$ F. Brassington, S. Pettit, Principles of Marketing, Prentice Hall, $4^{\text {th }}$ edition, Harlow, Essex 2006.

${ }^{20}$ R.J. Burke, op. cit., pp. 3-4. 


\begin{tabular}{|c|c|c|}
\hline 13 & $\begin{array}{l}\text { Barnett, Jermier and } \\
\text { Lafferty, } 2006\end{array}$ & $\begin{array}{l}\text { Observer's collective judgments of a corporation based on assessments of the fi- } \\
\text { nancial, social, and environmental impacts attributed to the corporate over time. }\end{array}$ \\
\hline 14 & $\begin{array}{l}\text { Abimbola and Ko- } \\
\text { cak, } 2007\end{array}$ & $\begin{array}{l}\text { Reputation refers to value judgments about an organization's qualities, trustworthi- } \\
\text { ness and reliability built up over time*. }\end{array}$ \\
\hline 15 & $\begin{array}{l}\text { Smaiziene and } \\
\text { Jucevicius, } 2009\end{array}$ & $\begin{array}{l}\text { Corporate reputation can be defined as socially transmissible company's (its char- } \\
\text { acteristics', practice's, behavior's and results', etc.) evaluation settled over a peri- } \\
\text { od of time among stakeholders, that represents expectations for the company's } \\
\text { actions, and level of trustworthiness, favorability and acknowledgement compar- } \\
\text { ing to rivals }{ }^{*+*} \text {. }\end{array}$ \\
\hline 16 & Burke, 2011 & $\begin{array}{l}\text { A corporate reputation is a function of the perceptions and attitudes toward it held } \\
\text { by individual members of a particular stakeholder group }{ }^{+* * *} \text {. }\end{array}$ \\
\hline 17 & $\begin{array}{l}\text { Adeosun and Gani- } \\
\text { yu, } 2013\end{array}$ & $\begin{array}{l}\text { Corporate reputation is...interpreted as an organizations ethos, goals and values } \\
\text { that create a sense of belonging among company's stakeholders }{ }^{*+4+*} \text {. }\end{array}$ \\
\hline
\end{tabular}

M. Gotsi, A.M. Wilson, Corporate reputation: seeking a definition, „Corporate Communications”, Vol. 6, No. 1/2001, pp. 24-30.

** T. Abimbola, A. Kocak, Brand, organization identity and reputation: SMEs as expressive organizations: A resources based perspective, "Qualitative Market Research: An International Journal”, Vol. 10, No. 4/2007, pp. 416-430.

I. Smaiziene, R. Jucevicius, Corporate Reputation: Multidisciplinary Richness and Search for a Relevant Definition, „Commerce of engineering decisions", Vol. 2/2009, pp. 91-101.

R.J. Burke, op. cit., pp. 3-4.

L.P.K. Adeosun, R.A. Ganiyu, Corporate Reputation as a Strategic Asset, "International Journal of Business and Social Science", Vol. 4, No. 2/2013, pp. 220-225.

Source: Own research based on K. Walker, A Systematic Review of the Corporate Reputation Literature: Definition, Measurement, and Theory, "Corporate Reputation Review", Vol. 12, No. 4/2010, pp. 357-387.

\section{THE METHODOLOGY OF RESEARCH}

To investigate whether interdisciplinary research on corporate reputation is feasible, the analysis focuses on how the term "corporate reputation" is understood in the fields of law and marketing. For research purposes, the concept understood as "a unit of knowledge abstracted from a set of characteristics attributed to a class of objects, relations, or entities" ${ }^{21}$ is distinguished from the term defined as "a word (simple term), multiword expression (complex term), symbol or formula that designates a particular concept within a given subject field" 22 . The focus of the paper is on the complex term "corporate reputation" that designates a concept in two subject fields: marketing and law. To fulfil the paper's purpose, the authors identify and compare the scopes of the concept(s) designated by the term "corporate reputation" as it is used

21 S. Pavel, D. Nolet, Handbook of Terminology, Translation Bureau, Canada. Public Works and Government Services Canada. Terminology and Standardization Directorate, Canadian Government Publishing, 2002, http://www.atesman.info/files/handbook.pdf

(28.07.2015), p. 105.

${ }^{22}$ Ibidem, p. 117

Ekonomia I Prawo. ECOnomics And LaW, Vol. 14, No. 2/2015 
in the domains of law and marketing ${ }^{23}$. Firstly, the concept(s) are analyzed in their own (respectively legal and marketing) contexts in order to determine their semantic features, the purposes and ways of the usage of the term. Subsequently, the concepts are compared with each other.

The analysis of a legal context is based on Polish law, and therefore the methods of comparative law are not applied. Due to a lack of the legal definition of corporate reputation, the scope of this concept is reconstructed on the basis of the analysis of contextual usage of the term "corporate reputation" in Polish legislation, case law and academic papers (see section 1). The reconstructed meaning and the scope of the concept "corporate reputation" in law is compared with the scope and semantic features of this concept determined on the basis of marketing scholar materials. Major research databases (including EBSCO, ProQuest, etc.) are used to identify academic papers that focused on corporate reputation. To be included in this paper, the selections has been narrowed down subjectively to the most relevant within the research topic. The corporate reputation is a two-word term, and therefore the meanings of "reputation" and especially of "corporate" are as well taken into consideration.

\section{THE RESEARCH PROCESS: REPUTATION OF WHOM? - THE MEANING OF "CORPORATE" IN LAW AND MARKETING}

To determine if the concepts of corporate reputation in law and marketing are comparable, it is necessary to investigate whether the term "corporate", to which reputation refers, denotes the same concept in legal and marketing fields. The English term used by both marketing and legal scholars is comprised of two words, the noun "reputation" and the adjective "corporate", which means "of or belonging to a corporation" ${ }^{4}$. The Polish legal phrase consists of two nouns. The first noun is "renoma" (repute) or very rarely "reputacja" (reputation), and the second noun is "przedsiębiorstwo" (corporation $^{25}$ ). However, the second noun is often replaced by scholars and judg-

${ }^{23}$ On concept analysis, see e.g. ibidem p. 120. The research is based on terminological concept analysis methods as described in A. Nuopponen, Methods of concept analysis - Towards systematic concept analysis, „LSP Journal”, Vol. 1, No. 2/2010, pp. 4-15.

${ }^{24}$ Longman Dictionary of Contemporary English, Longman Group UK Limited, reprinted by PWN Warsaw 1989, p. 230, the second meaning.

${ }^{25}$ In the English translation of Polish legal acts the term "enterprise" is used more often than "corporation" as an equivalent of "przedsiębiorstwo". 
es with the terms "przedsiębiorca" (entrepreneur) and "podmiot gospodarczy" (business entity) or "osoba prawna" (legal person). The two terms, "reputation of corporation" (renoma przedsiebiorstwa) and "reputation of entrepreneur" (renoma przedsiębiorcy) are the most common in legal language ${ }^{26}$. Therefore, the following terminological analysis focuses on the terms "corporation" and "entrepreneur".

In this terminological examination, two general observations should be considered. Firstly, neither "corporation" nor "entrepreneur" has a uniform meaning. The latter has various legal definitions in several legal acts ${ }^{27}$. As to the former, legal scholars have developed numerous theories of corporation ${ }^{28}$. One of them even identifies a corporation by its reputation. However, this approach to the corporation does not reflect the full meaning of this concept ${ }^{29}$.

Secondly, in Polish law, the terms "corporation" (przedsiębiorstwo) and "entrepreneur" (przedsiębiorca) are not equivalent. The Civil Code provides two separate legal definitions of each concept. In Article 551, corporation (enterprise) is defined as an organized set of tangible and intangible elements intended for conducting business activity. This provision specifies the examples of such elements but does not include reputation among them. However, legal scholars ${ }^{30}$ and judges ${ }^{31}$ recognize reputation as an intangible element of a corporation. Moreover, in the project of a new Polish Civil Code, reputation has been included in the list of corporate elements ${ }^{32}$. Furthermore, the elements of a corporation are protected by the law. This protection is guaranteed to an entrepreneur. Therefore, the phrase "reputation of an entrepreneur" is also in use.

${ }_{26}$ The Google search for "renoma przedsiębiorstwa" provided 1870 results, whereas "renoma przedsiebiorcy" - 462 results. Considering that "renoma" is typical term for legalese (in marketing "reputacja" is used), we can assume that results illustrate mostly the use of the terms in legal language.

27 See for instance: Ustawa z dnia 23 kwietnia 1964 r..., op. cit., art. 431; Obwieszczenie Marszatka Sejmu..., op. cit., art. 2; Ustawa z dnia 2 lipca 2004 r. o swobodzie dziatalności gospodarczej (Freedom of Economic Activity Act), Dz.U., No. 173, item 1807, art. 4.

${ }^{28}$ For the overview of Polish theories of corporation, see E. Norek, Przedsiębiorstwo w obrocie gospodarczym, LexisNexis, Warszawa 2008, p. 29; M. Warciński, Problem zróżnicowania definicji "przedsiębiorstwa" w polskim prawie i jego skutki prawne, Opracowania Instytutu Wymiaru Sprawiedliwości, Warszawa 2008.

${ }^{29}$ M. Warciński, op. cit., pp. 9-10.

${ }^{30}$ R. Trzaskowski, S. Rudnicki, Komentarz do ksiegi I, tytutu III, art. 551, [in:] J. Gudowski (ed.), Kodeks cywilny. Komentarz. Księga pierwsza. Częśc Ogólna, LexisNexis Warszawa 2014, pp. 295-296.

31 Cf. Judgment of the Supreme Administrative Court of June 20, 2006, II FSK 839/05.

32 Komisja Kodyfikacyjna Prawa Cywilnego działająca przy Ministrze Sprawiedliwości, Księga Pierwsza Kodeksu Cywilnego. Projekt z uzasadnieniem, Warszawa 2008, p. 76. 
In addition, according to scholars, Article 26 of the Suppression of Unfair Competition Act, which forbids disseminating untrue or misleading information about an enterprise, protects the "reputation of the enterprise (entrepreneur)"33. Although, the term "corporation" cannot generally be replaced with the term "entrepreneur", as used in the phrases "reputation of corporation" and "reputation of entrepreneur", the two terms are interchangeable. Nevertheless, there is a slight difference in the meaning of these two terms. The focus of the term "reputation of corporation" is on the reputation as an intangible element of a corporation, whereas the focus of the term "reputation of entrepreneur" is on the protection of the corporate reputation guaranteed to an entrepreneur.

In terms of marketing terminology, the examination of the above-mentioned marketing definitions of "corporate reputation" discloses that "corporate" refers to corporation, not to an entrepreneur. Only one definition (def. 7) indicates a person; in the others, the marketing scholars refer to a firm (definitions $1,2,3,4,5,6,8,12$ ), a company (definitions $3,8,15,17$ ), an organization (definitions $9,10,14,17$ ), a person or another entity (definition 7 ), a producer (definition 11), and a corporation (definition 13). For some scholars, "a firm" and "a company" are synonymous (see definition 3, 8). Others use "an organization" and "a company" as interchangeable (definition 17). Neither corporation nor other terms appearing in the definitions have a uniform meaning. The term "corporation" is not defined in the marketing domain, as it is used in the everyday sense, including the legal meaning of this concept. Some marketing scholars are inspired by legal definitions of corporation to build their own, as for instance Hughes et al., who defines corporation as "an artificial person created by law with most of the legal rights of a real person, including the rights to start and operate a business, to buy or sell property, to borrow money, to sue or be sued, and to enter into binding contracts" 34 . Although the basis of this definition is not Polish law but an U.S. American Supreme Court decision, it is worth mentioning, as it emphasizes the similarity between a corporation - an artificial person and a real person. This similarity in Polish legalese is reflected in two phrases: reputation of enterprise (corporation) and reputation of entrepreneur.

${ }^{33}$ J. Raglewski, Komentarz do art. 26 ustawy o zwalczaniu nieuczciwej konkurencji, [in:] M. Zdyb (ed.), Ustawa o zwalczaniu nieuczciwej konkurencji. Komentarz, LEX, Warszawa 2011.

${ }^{34}$ R. Hughes, W. Pride, J. Kapoor, Business Foundations, $2^{\text {nd }}$ edition, South-Western Cengage, Boston, MA 2011, p. 113. 


\section{THE RESULTS OF THE RESEARCH: CORPORATE REPUTATION - THE LACK OF A UNIFORM DEFINITION}

While searching for the meaning of a legal act, interpreters often do not limit themselves only to the literal (purely linguistic) sense of an interpreted text, but they focus on the purpose of the regulation. Correspondingly, the core of the meaning of corporate reputation can be found in the aim to coin this concept in the fields of law and marketing, or in other words, in the objectives of marketing and legal research. The understanding of why the research on corporate reputation is undertaken by marketing and legal scholars should not only elucidate the sense of the concept but explain the differences in the meaning.

Marketing investigation of corporate reputation aims to create a competitive advantage ${ }^{35}$ by developing a good corporation reputation. Therefore, the subject of the research is the creation ${ }^{36}$ and evaluation of corporate reputation $^{37}$. Hence, the process of building the reputation by a corporation is investigated. This becomes obvious when the marketing definitions of corporate reputation are examined. Most of them use expressions related to a process of building or evaluating corporate reputation ${ }^{38}$.

Legal research on corporate reputation is undertaken to guarantee the best legal protection of the reputation. Consequently, case law and legal research create the catalogue of reputational harms instead of the definition of corporate reputation. Neither legal regulation nor research focus on developing corporate reputation, but on the effect of such development. The lack of interest in the process of reputation creation is reflected in the statement of the Polish Supreme Court "not only the reputation that results from the previous actions of a legal person is taken into account but also the reputation which is assumed from the moment of the creation of a legal person" ${ }^{39}$. As a result, lawyers perceive reputation as something stable. Therefore, in definitions in a le-

35 Cf., for instance, definition 2 which describes corporate reputation as a competitive process or definitions 3, 8 and 15 which mention comparison with (leading) rivals.

${ }^{36}$ H.M. Aula, J. Tienari, Becoming "world-class"? Reputation-building in a university merger, „Critical perspectives on international business”, Vol. 7, No. 1/2011, pp. 7-29.

${ }^{37}$ J.L.F. Sanchez, L.L. Sotorrio, The Creation of Value Through Corporate Reputation, "Journal of Business Ethics", Vol. 76, No. 3/2007, pp. 335-346.

38 Cf. "the firm's/company's past actions" (definitions: 1., 3.); "the outcome of a competitive process" (definition: 2.), "evaluation of company over time" (definition: 8), “...impacts attributed to the corporate over time" (definition: 13.); “...built up over time” (definition: 14.), "evaluation settled over a period of time" (definition: 15.).

39 Judgment of the Supreme Court of June 6, 2005, op. cit. 
gal discipline, as opposed to opinions, which are more likely to be modified, a good name is chosen as a genus. However, reputation has a dynamic character.

Thus, while comparing the meaning of corporate reputation in law and marketing, two approaches towards this concept can be distinguished: firstly, reputation as a result (i.e. opinions about the corporation), and secondly, reputation as a process (all actions undertaken by a corporation or an entrepreneur that create a good image and a positive perception of the corporation). Legal regulation and research are interested only in reputation as a result (or a good name reflected in opinions), whereas marketing focuses on the two facets of reputation: firstly, on actions to build reputation (reputation as a process), and secondly, on the opinions about a corporation (reputation as a result). Consequently, the research undertaken within the two disciplines can be combined, especially if both law and marketing focus on reputation as a result. Particularly, the criteria developed by marketing scholars to evaluate reputation can be expedient for judges when deciding whether corporate reputation has been harmed.

In addition, the reasons for building reputation by marketing actions and for protecting reputation by law are different. Companies use their reputation to create a competitive advantage. The law provides protection when reputational harm can make conducting business activity impossible. Consequently, only if a competitive advantage is indispensable to conduct business activity are the legal concept and marketing concept of corporate reputation the same (synonymous in a logical sense).

\section{CONCLUSIONS}

The same English expression "corporate reputation" does not mean the same in the domain of law and in the field of marketing. This statement is reflected in the Polish language by the use of two different phrases: "renoma przedsięborcy" in legalese and "reputacja przedsiębiorstwa" in the language of marketing. The terms must denote different concepts in these fields, because marketing and law coined them for different purposes. Marketing focuses on the process of creating and developing corporate reputation and on its evaluation, whereas law protects to the reputation, i.e. the result of this marketing process.

According to cognitive linguistics the meaning of a word comprises linguistic and extralinguistic knowledge. The latter is defined as the knowledge of the world. As marketing and legal scholars concentrate on different aspects 
of the world, their extralinguistic knowledge is not the same. On the other hand, marketing experts and lawyers act in the same market and have the same client, i.e. an entrepreneur and companies. Therefore, it is important to bring legal and marketing knowledge together. This is possible mainly due to interdisciplinary research. A better understanding of what is behind the term "corporate reputation" can help to provide full protection by legislation and in courts, and better communication between a lawyer and an entrepreneur.

The differences in the meaning of the term do not imply that communication between the two disciplines in the area of corporate reputation is not possible. On the contrary, the awareness of these differences makes interdisciplinary research on corporate reputation not only possible but also prolific.

\section{BIBLIOGRAPHY}

Abimbola T., Kocak A., Brand, organization identity and reputation: SMEs as expressive organizations: A resources based perspective, "Qualitative Market Research: An International Journal”, Vol. 10, No. 4/2007, http://dx.doi. org/10.1108/13522750710819748.

Adeosun L.P.K., Ganiyu R.A., Corporate Reputation as a Strategic Asset, „International Journal of Business and Social Science", Vol. 4, No. 2/2013.

Aula H.M., Tienari J., Becoming "world-class"? Reputation-building in a university merger, „Critical Perspectives on International Business”, Vol. 7, No. 1/2011, http:// dx.doi.org/10.1108/17422041111103813.

Brassington F., Pettit S., Principles of Marketing, Prentice Hall, $4^{\text {th }}$ edition, Harlow, Essex 2006.

Burke R.J., Corporate Reputations: Development, Maintenance, Change and Repair, [in:] R.J. Burke, G. Martin, C.L. Cooper (eds.), Corporate Reputation. Managing Opportunities and Threats, Gower, Farnham, Surrey 2011.

Featuring Black's Law Dictionary, http://thelawdictionary.org (20.12.2014).

Gotsi M., Wilson A.M., Corporate reputation: seeking a definition, „Corporate Communications", Vol. 6, No. 1/2001, http://dx.doi.org/10.1108/13563280110381189.

Hughes R., Pride W., Kapoor J., Business Foundations, $2^{\text {nd }}$ edition, South-Western Cengage, Boston, MA 2011.

Judgment of the Court of Appeals in Warsaw of May 23, 2006, VI ACa 1221/05.

Judgment of the Court of Justice of June 18, 2009, C-487/07.

Judgment of the District Administrative Court of February 6, 2009, VI SA/Wa 1483/08. Judgment of the District Administrative Court of November 11, 2008, VI SA/Wa 1388/07.

Judgment of the Supreme Administrative Court of June 20, 2006, II FSK 839/05.

Judgment of the Supreme Administrative Court of September 6, 2013, I ACa 456/13. 
Judgment of the Supreme Court of June 6, 2005, III CK 622/04.

Judgment of the Supreme Court of November 14, 1986, II CR 295/86.

Judgment of the Supreme Court of October 16, 2014, III CSK 275/13.

Komisja Kodyfikacyjna Prawa Cywilnego działająca przy Ministrze Sprawiedliwości, Księga Pierwsza Kodeksu Cywilnego. Projekt z uzasadnieniem, Warszawa 2008. Longman Dictionary of Contemporary English, Longman Group UK Limited, reprinted by PWN Warsaw 1989.

Merriam-Webster, Reputation, http://www.merriam-webster.com/dictionary/reputation (22.09.2014).

Norek E., Przedsiębiorstwo w obrocie gospodarczym, LexisNexis, Warszawa 2008.

Nuopponen A., Methods of concept analysis - Towards systematic concept analysis, „LSP Journal", Vol. 1, No. 2/2010.

Obwieszczenie Marszatka Sejmu Rzeczypospolitej Polskiej z dnia 26 czerwca 2003 r. w sprawie ogtoszenia jednolitego tekstu ustawy o zwalczaniu nieuczciwej konkurencji (Suppression of Unfair Competition Act of June 26, 2003), Dz.U., No. 153, item 1503.

Parker H.M., Fink J.S., Arrest Record or Openly Gay: The Impact of Athletes' Personal Lives on Endorser Effectiveness, „Sport Marketing Quarterly”, Vol. 21, No. 2/2012.

Pavel S., Nolet D., Handbook of Terminology, Translation Bureau, Canada. Public Works and Government Services Canada. Terminology and Standardization Directorate, Canadian Government Publishing, 2002, http://www.atesman.info/files/ handbook.pdf (28.07.2015).

Raglewski J., Komentarz do art. 26 ustawy o zwalczaniu nieuczciwej konkurencji, [in:] M. Zdyb (ed.), Ustawa o zwalczaniu nieuczciwej konkurencji. Komentarz, LEX, Warszawa 2011.

Saidov D., Damages: The Need for Uniformity, „Journal of Law and Commerce” Vol. 25, No. $1 / 2005$.

Sanchez J.L.F., Sotorrio L.L., The Creation of Value Through Corporate Reputation, "Journal of Business Ethics”, Vol. 76, No. 3/2007, http://dx.doi.org/10.1007/ s10551-006-9285-0.

Słownik Języka Polskiego, http://sjp.pwn.pl/szukaj/reputacja.html (20.12.2014).

Smaiziene I., Jucevicius R., Corporate Reputation: Multidisciplinary Richness and Search for a Relevant Definition, „Commerce of engineering decisions”, Vol. 2/2009.

The Free Dictionary, http://www.thefreedictionary.com/reputation (20.12.2014).

Trzaskowski R., Rudnicki S., Komentarz do ksiegi I, tytutu III, art. 551, [in:] J. Gudowski (ed.), Kodeks cywilny. Komentarz. Księga pierwsza. Częś́ Ogólna, LexisNexis Warszawa 2014.

Ustawa z dnia 2 lipca 2004 r. o swobodzie dziatalności gospodarczej (Freedom of Economic Activity Act), Dz.U., No. 173, item 1807.

Ustawa z dnia 23 kwietnia 1964 r. - Kodeks cywilny (Civil Code, April 23, 1964), Dz.U., No. 16, item 93.

Walker K., A Systematic Review of the Corporate Reputation Literature: Definition, Measurement, and Theory, „Corporate Reputation Review”, Vol. 12, No. 4/2010, http://dx.doi.org/10.1057/crr.2009.26. 
Warciński M., Problem zróżnicowania definicji „przedsiębiorstwa” w polskim prawie i jego skutki prawne, Opracowania Instytutu Wymiaru Sprawiedliwości, Warszawa 2008.

Wróblewski B., Język prawny i prawniczy, Polska Akademia Umiejętności, Kraków 1948. 
